\title{
Experimental partitioning of halogens and other trace elements between olivine, pyroxenes, amphibole and aqueous fluid at 2 GPa and $900-1,300{ }^{\circ} \mathrm{C}$
}

\author{
Alessandro Fabbrizio • Roland Stalder • \\ Kathrin Hametner • Detlef Günther • \\ Katharina Marquardt
}

Received: 11 March 2013/Accepted: 31 May 2013/Published online: 19 June 2013

(C) The Author(s) 2013. This article is published with open access at Springerlink.com

\begin{abstract}
We present new partition coefficients for various trace elements including $\mathrm{Cl}$ between olivine, pyroxenes, amphibole and coexisting chlorine-bearing aqueous fluid in a series of high-pressure experiments at $2 \mathrm{GPa}$ between 900 and $1,300{ }^{\circ} \mathrm{C}$ in natural and synthetic systems. Diamond aggregates were added to the experimental capsule set-up in order to separate the fluid from the solid residue and enable in situ analysis of the quenched solute by LA-ICP-MS. The chlorine and fluorine contents in mantle minerals were measured by electron microprobe, and the nature of $\mathrm{OH}$ defects was investigated by infrared spectroscopy. Furthermore, a fluorine-rich olivine from one selected sample was investigated by TEM. Results reveal average $\mathrm{Cl}$ concentrations in olivine and pyroxenes around $20 \mathrm{ppm}$ and up to $900 \mathrm{ppm} \mathrm{F}$ in olivine, making olivine an important repository of halogens in the mantle. Chlorine is always incompatible with $\mathrm{Cl}$ partition coefficients $D_{\mathrm{Cl}}^{\text {olivine/fluid }}$ varying between $10^{-5}$ and $10^{-3}$, whereas $D_{\mathrm{Cl}}^{\text {orthopyroxene/fluid }}$ and $D_{\mathrm{Cl}}^{\text {clinopyroxene/fluid }}$ are $\sim 10^{-4}$ and $D_{\mathrm{Cl}}^{\text {amphibole/fluid }}$ is
\end{abstract}

Communicated by J. Hoefs.

Electronic supplementary material The online version of this article (doi:10.1007/s00410-013-0902-5) contains supplementary material, which is available to authorized users.

A. Fabbrizio $(\bowtie) \cdot$ R. Stalder

Institute of Mineralogy and Petrography, University

of Innsbruck, Innrain 52f, 6020 Innsbruck, Austria

e-mail: Alessandro.Fabbrizio@uibk.ac.at

K. Hametner · D. Günther

Lab of Inorganic Chemistry, ETH Zürich, Wolfgang-Pauli-Str.

10, 8093 Zurich, Switzerland

K. Marquardt

Deutsches GeoForschungsZentrum, Section 3.3, Telegrafenberg,

14473 Potsdam, Germany $\sim 5 \times 10^{-3}$. Furthermore, partitioning results for incompatible trace element show that compatibilities of trace elements are generally ordered as $D^{\text {amph/fluid }} \approx$ $D^{\text {cpx/fluid }}>D^{\text {opx/fluid }}>D^{\text {ol/fluid }}$ but that $D^{\text {mineral/fluid }}$ for $\mathrm{Li}$ and $\mathrm{P}$ is very similar for all observed silicate phases. Infrared spectra of olivine synthesized in a F-free Tibearing system show absorption bands at 3,525 and $\sim 3,570 \mathrm{~cm}^{-1}$. In $\mathrm{F} \pm \mathrm{TiO}_{2}$-bearing systems, additional absorption bands appear at $\sim 3,535, \sim 3,595,3,640$ and $3,670 \mathrm{~cm}^{-1}$. Absorption bands at $\sim 3,530$ and $\sim 3,570$ $\mathrm{cm}^{-1}$, previously assigned to humite-like point defects, profit from low synthesis temperatures and the presence of F. The presence of planar defects could not be proved by TEM investigations, but dislocations in the olivine lattice were observed and are suggested to be an important site for halogen incorporation in olivine.

Keywords Halogens - Trace element partitioning . Mantle $\cdot$ Defects · TEM

\section{Introduction}

Mantle minerals such as olivine, ortho- and clinopyroxene can host up to several hundreds ppm water (Rauch and Keppler 2002; Hirschmann et al. 2005; Stalder et al. 2005, 2008; Grant et al. 2007a; Tenner et al. 2009). The incorporation mechanism of $\mathrm{OH}$ in mantle minerals is important for understanding the rheology, partial melting, diffusion, electrical conductivity, seismic wave speeds and attenuation of the mantle and has been studied intensely in the previous decades (e.g., Bell and Rossman 1992; Hirth and Kohlstedt 1996; Karato and Jung 1998). In contrast, the role of the halogens $\mathrm{F}$ and $\mathrm{Cl}$ in the mantle is not well investigated. From geochemical considerations $(\mathrm{Cl} / \mathrm{K}$ and 
$\mathrm{F} / \mathrm{P}$ ratios of melt inclusions from mid-ocean ridge basalts and the estimated $\mathrm{K}$ and $\mathrm{P}$ contents of the upper mantle), the abundance of chlorine in the mantle is estimated to approximately $1 \mathrm{ppm}$ and that of fluorine to $16 \mathrm{ppm}$ (Saal et al. 2002). Despite their low abundances in the mantle, halogens exert a significant role on the genesis and evolution of magmas. Halogens play an important role in volcanic and related magmatic systems (Aiuppa et al. 2009; Baker and Balcone-Boissard 2009; Webster et al. 2009). Halogens are separated from magma in the Earth's crust during cooling and crystallization (Carroll and Webster 1994) and exert significant impact on the genesis of hydrothermal systems (e.g., Reed 1997) and on the transport of ore-forming metals (Yardley 2005; Vigneresse 2009).

Halogen solubilities in nominally anhydrous mantle minerals at mantle conditions are scarcely documented, but seem to be much higher than observed in natural samples (Beyer et al. 2012). Experimental results in the system $\mathrm{Mg}_{2} \mathrm{SiO}_{4}-\mathrm{MgF}_{2}$ (Bromiley and Kohn 2007) reveal up to $0.45 \mathrm{wt} \% \mathrm{~F}$ in forsterite, but no apparent correlation between $\mathrm{F}$ and $\mathrm{Mg}$ concentrations in the olivine could be established, and the incorporation mechanisms could not be solved. In contrast, $\mathrm{Cl}$ solubilities are much lower. Chlorine concentrations for forsterite and enstatite in fluid-bearing systems cluster around $3 \mathrm{ppm}$ in the system forsteriteenstatite-pyrope- $\mathrm{H}_{2} \mathrm{O}-\mathrm{MgCl}_{2}$ (Bernini et al. 2013). In contrast, $\mathrm{Cl}$ concentrations around $20 \mathrm{ppm}$ were observed in the system $\mathrm{MgO}-\mathrm{SiO}_{2}-\mathrm{H}_{2} \mathrm{O} \pm \mathrm{TiO}_{2} \pm \mathrm{Al}_{2} \mathrm{O}_{3}$ under similar $P-T$ conditions (Fabbrizio et al. 2013), where the enhanced $\mathrm{Cl}$ solubilities in forsterite in the presence of $\mathrm{TiO}_{2}$ suggest a $\mathrm{Cl}$ incorporation in forsterite via the stabilization of defects that are stabilized by Ti, e.g., humitetype defects. Ti plays an important role in the formation of hydroxyl point defects in olivine associated with trace $\mathrm{Ti}$ substitutions (Berry et al. 2005), and planar humite type associated with $\mathrm{Ti}$ has been detected in olivine from different localities (Kitamura et al. 1987; Drury 1991; Risold et al. 2001; Hermann et al. 2007) by transmission electron microscopy (TEM). Both kinds of defects are able to host halogens that substitute some of the $\mathrm{OH}$. In addition to planar and point defects, the growth of nanometer-sized Ti-clinohumite nuclei during hydrous alteration in olivine at $8 \mathrm{GPa}$ and $1,300 \mathrm{~K}$ has been described (Wirth et al. 2001), otherwise no detailed TEM studies have been carried out to confirm the presence of humite-type defects in synthetic olivine. Olivine crystals that have been investigated by TEM and revealed humite-type planar defects exhibit IR absorption bands at 3,564 and $3,394 \mathrm{~cm}^{-1}$, identical in energy to absorption bands in Ti-clinohumite (Hermann et al. 2007). In contrast, Ti-related $\mathrm{OH}$ point defects in olivine cause IR absorption bands at 3,525 and $3,572 \mathrm{~cm}^{-1}$ (Berry et al. 2005). Partitioning experiments at upper mantle conditions between nominally halogen-free minerals and coexisting basaltic melts both in natural and in synthetic systems show that (1) $\mathrm{F}$ and $\mathrm{Cl}$ are always incompatible in mantle minerals, (2) the compatibilities are generally ordered as $D^{\mathrm{Cpx} / \text { melt }}>D^{\mathrm{Opx} / \mathrm{melt}}>D^{\mathrm{Grt} / \mathrm{melt}}>$ $D^{\mathrm{Ol} / \mathrm{melt}}>D^{\mathrm{Plag} / \mathrm{melt}}$ and (3) $\mathrm{F}$ is less incompatible than $\mathrm{Cl}$ (Beyer et al. 2012; Dalou et al. 2012).

In this study, we present new experimental results derived from synthesis experiments at $2 \mathrm{GPa}$ and 900-1,300 ${ }^{\circ} \mathrm{C}$ for $\mathrm{F}$ and $\mathrm{Cl}$ incorporation in olivine, ortho- , clinopyroxene, and amphibole and mineral/fluid partition coefficient for $\mathrm{Cl}$ in the system $\mathrm{MgO}-\mathrm{SiO}_{2}-\mathrm{H}_{2} \mathrm{O} \pm$ $\mathrm{TiO}_{2} \pm \mathrm{NaCl} \pm \mathrm{MgF}_{2} \pm \mathrm{CaF}_{2}$ and in natural composition doped with $\mathrm{TiO}_{2}, \mathrm{NaCl}$ or $\mathrm{CaF}_{2}$. A combination of electron microprobe and LA-ICP-MS was used to analyze $\mathrm{Cl}$ in the resulting phases. The quality and quantity of $\mathrm{OH}$ defects in olivine were characterized by IR spectroscopy, and transmission electron microscopy (TEM) was used to investigate the relations between the $\mathrm{OH}$-related IR absorption bands and humite-type defects.

\section{Experimental and analytical methods}

Starting materials and sample preparation

The starting materials for the experimental runs consisted of a natural peridotite from Stöppling/Germany (details concerning petrography see Oehm et al. 1983; composition was determined by XRF: $\mathrm{SiO}_{2}=44.2 \mathrm{wt} \% ; \mathrm{Al}_{2} \mathrm{O}_{3}=1.3 \mathrm{wt} \%$; $\mathrm{Fe}_{2} \mathrm{O}_{3}=9.4 \mathrm{wt} \% ; \mathrm{MnO}=0.1 \mathrm{wt} \% ; \mathrm{MgO}=43.6 \mathrm{wt} \%$; $\mathrm{CaO}=1.3 \mathrm{wt} \%)$ and of a synthetic $\mathrm{MSH} \quad(\mathrm{MgO}=$ $40.3 \mathrm{wt} \% ; \mathrm{SiO}_{2}=41.7 \mathrm{wt} \% ; \mathrm{H}_{2} \mathrm{O}=18 \mathrm{wt} \%$ ) powder both doped with $\mathrm{TiO}_{2}, \mathrm{NaCl}, \mathrm{CaF}_{2}$ or $\mathrm{MgF}_{2}$ (Table 1).

Starting mixtures were prepared by grounding the peridotite and the synthetic $\mathrm{Mg}(\mathrm{OH})_{2}-\mathrm{SiO}_{2}$ mixture in an agate mortar under ethanol for $1 \mathrm{~h}$ and subsequently in an automatic milling machine for $1 \mathrm{~h}$. The doping agents were then added to the starting mixtures in the desired amount. In addition, barium was added as $\mathrm{BaTiO}_{3}$ to the peridotite mixture. Barium is highly incompatible in mantle minerals. Therefore, it resides preferably in the fluid or melt phase and can be used as internal standard for quantification of LA-ICP-MS analyses. The doped starting mixtures were ground again in the agate mortar under ethanol for $1 \mathrm{~h}$ to achieve chemical homogeneity.

As sample containers, we used Pt capsules with an outer (inner) diameter of 3.0 (2.6) $\mathrm{mm}$. For experiments with the diamond trap, a Pt ring with an inner diameter of $2.1 \mathrm{~mm}$ and a height of $1 \mathrm{~mm}$ was inserted into the $\mathrm{Pt}$ capsule. Then, $\sim 6 \mu \mathrm{H}_{2} \mathrm{O}$ was added to the capsule, corresponding to $15 \mathrm{wt} \%$ of the starting powder + water mixture. The capsule was then filled with 6-7 mg of synthetic diamond 
Table 1 Starting mixtures, experimental conditions ${ }^{\mathrm{a}}$ and phase relations of the run products

\begin{tabular}{|c|c|c|c|c|}
\hline Run & Starting material & $T\left({ }^{\circ} \mathrm{C}\right)$ & Time (h) & Run products identified \\
\hline $\mathrm{Cl}-22$ & Peridotite $+0.3 \% \mathrm{TiO}_{2}+22 \% \mathrm{NaCl}$ & 1,300 & 24 & ol, salt, fluid \\
\hline $\mathrm{Cl}-23$ & Peridotite $+0.3 \% \mathrm{TiO}_{2}+22 \% \mathrm{NaCl}$ & 1,200 & 48 & ol, salt, fluid \\
\hline $\mathrm{Cl}-24$ & Peridotite $+0.3 \% \mathrm{TiO}_{2}+22 \% \mathrm{NaCl}$ & 1,100 & 72 & ol, opx, salt, fluid \\
\hline $\mathrm{Cl}-25$ & Peridotite $+0.3 \% \mathrm{TiO}_{2}+22 \% \mathrm{NaCl}$ & 1,000 & 96 & ol, opx, cpx, salt, fluid \\
\hline $\mathrm{Cl}-26$ & Peridotite $+0.3 \% \mathrm{TiO}_{2}+22 \% \mathrm{NaCl}$ & 900 & 144 & ol, opx, cpx, amph, salt, fluid \\
\hline $\mathrm{Cl}-22^{\mathrm{b}}$ & Peridotite $+0.3 \% \mathrm{TiO}_{2}+22 \% \mathrm{NaCl}$ & 1,300 & 24 & ol, salt, fluid \\
\hline $\mathrm{Cl}-23^{\mathrm{b}}$ & Peridotite $+0.3 \% \mathrm{TiO}_{2}+22 \% \mathrm{NaCl}$ & 1,200 & 48 & ol, salt, fluid \\
\hline $\mathrm{Cl}-24^{\mathrm{b}}$ & Peridotite $+0.3 \% \mathrm{TiO}_{2}+22 \% \mathrm{NaCl}$ & 1,100 & 72 & ol, opx, salt, fluid \\
\hline $\mathrm{Cl}-25^{\mathrm{b}}$ & Peridotite $+0.3 \% \mathrm{TiO}_{2}+22 \% \mathrm{NaCl}$ & 1,000 & 96 & ol, opx, cpx, salt, fluid \\
\hline $\mathrm{Cl}-26^{\mathrm{b}}$ & Peridotite $+0.3 \% \mathrm{TiO}_{2}+22 \% \mathrm{NaCl}$ & 900 & 144 & ol, opx, cpx, amph, salt, fluid \\
\hline $\mathrm{F}-2$ & $\mathrm{MSH}+0.3 \% \mathrm{TiO}_{2}+1 \% \mathrm{CaF}_{2}$ & 1,300 & 24 & fo, en, salt, fluid \\
\hline F-3 & $\mathrm{MSH}+0.3 \% \mathrm{TiO}_{2}+1 \% \mathrm{CaF}_{2}$ & 1,200 & 48 & fo, chu, en, salt, fluid \\
\hline $\mathrm{Cl}-\mathrm{F}-1$ & $\mathrm{MSH}+22 \% \mathrm{NaCl}+2 \% \mathrm{MgF}_{2}$ & 1,200 & 48 & fo, en, salt, fluid \\
\hline F-1 & $\mathrm{MSH}+0.3 \% \mathrm{TiO}_{2}+1 \% \mathrm{CaF}_{2}$ & 1,000 & 96 & fo, en, di, tr, tlc ${ }^{\mathrm{d}}$, salt, fluid \\
\hline $\mathrm{F}-5^{\mathrm{c}}$ & Peridotite $+0.3 \% \mathrm{TiO}_{2}+22 \% \mathrm{NaCl}+2 \% \mathrm{CaF}_{2}$ & 1,300 & 24 & ol, sp, salt, fluid \\
\hline $\mathrm{F}-4^{\mathrm{c}}$ & Peridotite $+0.3 \% \mathrm{TiO}_{2}+22 \% \mathrm{NaCl}+2 \% \mathrm{CaF}_{2}$ & 1,300 & 24 & ol, salt, fluid \\
\hline F-6 & Peridotite $+0.3 \% \mathrm{TiO}_{2}+22 \% \mathrm{NaCl}+2 \% \mathrm{CaF}_{2}$ & 1,300 & 24 & ol, opx, salt, fluid \\
\hline F-7 & Peridotite $+0.3 \% \mathrm{TiO}_{2}+22 \% \mathrm{NaCl}+2 \% \mathrm{CaF}_{2}$ & 1,100 & 72 & ol, opx, salt, fluid \\
\hline
\end{tabular}

$O l$ olivine, opx orthopyroxene, $c p x$ clinopyroxene, amph amphibole, fo forsterite, en enstatite, $c h u$ clinohumite, di diopside, $t l c$ talc, $t r$ tremolite, $s p$ spinel

a All runs were performed at a pressure of $2 \mathrm{GPa}$

${ }^{\mathrm{b}}$ Experiment performed with diamond trap

${ }^{c}$ Capsule lined with Ni (F-4) and Fe (F-5) foil

d Supposed by mixed analysis fo + tlc (Table 3 )

crystals (grain size $20 \mu \mathrm{m}$ ) kindly provided by Servsix $\mathrm{GmbH}$ (Karlstein, Germany) and with $35-55 \mathrm{mg}$ of the starting material powder. For experiments without the diamond trap, the set-up of the capsule was the same except for the Pt ring and for the diamond crystals that were not used. For experiments with the MSH mixtures, $2 \mu \mathrm{H}_{2} \mathrm{O}$ was added to the capsule. The capsule was welded while cooled in water, and the weight of the capsule was compared before and after welding to ensure that no water was lost during welding. The sealed capsule was squeezed to a final cylindrical shape with a length of 5.5-6.5 mm and then held at $120^{\circ} \mathrm{C}$ for $24 \mathrm{~h}$, in order to check whether the capsule was sealed properly.

\section{Experiments}

Experiments were carried out in an end-loaded pistoncylinder apparatus at $2 \mathrm{GPa}$ and temperatures in the range of $900-1,300{ }^{\circ} \mathrm{C}$ for durations between 1 and 6 days at Innsbruck University (Table 1). The concentric cylindrical high-pressure assemblies consist (from outside to inside) of a lead foil wrapped around a talc cell, a Pyrex cylinder, a graphite furnace and inner pieces of crushable alumina sleeves. In two experiments, the interior walls of the capsules were lined with $\mathrm{Ni}$ (run F-4) and Fe foil (run F-5) to control the $\mathrm{fO}_{2}$ (Table 1). At pressure and temperature of interest $\left(2.0 \mathrm{GPa}\right.$ and $\left.1,300{ }^{\circ} \mathrm{C}\right)$, the calculated $\log f \mathrm{O}_{2}$ for the controlling reaction $\mathrm{Fe}-\mathrm{FeO}$ is $\sim 3 \log$ units below the QFM buffer (QFM-3) and for the reaction $\mathrm{Ni}-\mathrm{NiO}$ is $\sim 1.5$ $\log$ units above the QFM buffer (QFM + 1.5) (O'Neill 1988; O'Neill and Pownceby 1993). Run temperatures were controlled within $\sim 1{ }^{\circ} \mathrm{C}$ of the set point using $\mathrm{Pt} / \mathrm{Pt}_{90} \mathrm{Rh}_{10}$ thermocouples accurate to within $\pm 3{ }^{\circ} \mathrm{C}$. The range in temperature across the length of the capsules during the experiments is estimated to be less than $20^{\circ} \mathrm{C}$. The experimental charge is placed in the hotspot of the experimental assembly to prevent unwanted crystal growth within the diamond trap (Aerts et al. 2010). No pressure correction was applied to the EMF. The power output was monitored during the entire duration of all runs in order to ensure that no temperature drift occurred. Each experiment was initiated by gently increasing the sample pressure to approximately $0.25 \mathrm{GPa}$ followed by a heating to $1,400{ }^{\circ} \mathrm{C}$ at a rate of $15{ }^{\circ} \mathrm{C} / \mathrm{min}$ and a simultaneous pressure increase until the final pressure was reached. To grow relatively large, high-quality crystals necessary for IR spectroscopy, 
synthesis experiments were heated to $1,400{ }^{\circ} \mathrm{C}$ and then slowly cooled to final temperature at a rate of $6^{\circ} \mathrm{C} / \mathrm{h}$. Depending on the temperature, the experimental run time was in the range 24-144 h (Table 1), corresponding to the time needed to achieve equilibrium in similar systems under similar conditions (Stalder et al. 2001; Stalder and Ulmer 2001; Fabbrizio et al. 2013). All runs were terminated by switching off the power. After decompression, the charge was removed from the assembly, and the recovered capsule was weighed and pierced to check for potential leakage. When pierced, the $\mathrm{pH}$ of the extruding fluid was checked with indicator paper; the checked fluid was in all cases neutral $(\mathrm{pH}=7)$, indicating that the possibly dissolved alkalis are balanced by chlorine, that $\mathrm{Al}$ acidic and basic species are negligible and that neutral complex such as $\mathrm{NaAl}(\mathrm{OH})_{4}$ may form. Subsequently, the pierced capsule was dried in an oven at $120{ }^{\circ} \mathrm{C}$ (upon drying, salt crystals formed at the opening of the capsule) and weighed again. Usually, the weight loss upon drying corresponds to 90-100 \% of the initial water content. In the two samples buffered by the reactions $\mathrm{Fe}-\mathrm{FeO}$ and $\mathrm{Ni}-\mathrm{NiO}$, remnant metal foil from the oxygen buffer material and brightly colored crystalline material was recovered from the capsule. The metal foil was analyzed by EDS during the EMPA session. All recovered capsules were embedded in epoxy and ground by hand. As soon as the trap became visible, the sample was impregnated with epoxy to prevent destruction during preparation. Later, the capsule was ground until its maximum cross section was exposed.

\section{Electron microprobe}

Electron microprobe measurements were taken using a Jeol Superprobe 8100 at Innsbruck University. The crystals were analyzed with an electron beam energy of $15 \mathrm{keV}$, a beam current of $10 \mathrm{nA}$, a focused beam and counting times of $20 \mathrm{~s}$. Subsequently, $\mathrm{Ti}, \mathrm{Na}, \mathrm{Cl}$ and $\mathrm{F}$ were measured with a beam current of $400 \mathrm{nA}$ and 240-s counting time on peak and $120 \mathrm{~s}$ on the background. A detailed explanation of the analytical protocol to measure chlorine concentrations, including a comparison with samples for which the $\mathrm{Cl}$ contents were independently determined, is reported in Fabbrizio et al. (2013). Quartz ( $\mathrm{Si})$, diopside $(\mathrm{Ca})$, olivine $(\mathrm{Mg})$, rutile $(\mathrm{Ti})$, aegirine $(\mathrm{Na})$, atacamite $(\mathrm{Cl})$, corundum $(\mathrm{Al})$, chromite $(\mathrm{Cr})$, almandine (Fe), rhodonite (Mn), Ni-olivine (Ni) and F-topaz (F) were used as standards. Replicate analyses were carried out on the same sample (30-40 points in each sample) to check for compositional homogeneity. Limits of detection were $2 \mathrm{ppm}$ for $\mathrm{Cl}, 6 \mathrm{ppm}$ for $\mathrm{Na}, 9 \mathrm{ppm}$ for $\mathrm{Ti}$ and $15 \mathrm{ppm}$ for F. Associated relative errors (based on counting statistics) were less than $10 \%$ for $\mathrm{Cl}$, less than $5 \%$ for $\mathrm{Na}, \sim 20 \%$ for $\mathrm{Ti}$ and less than $1 \%$ for F. Due to the overlap of the $\mathrm{Fe} L \alpha$ over the $\mathrm{F} K \alpha$, fluorine was analyzed only in the Fe-free experiments. The BSE images show the absence of fluid inclusions inside the crystals and the absence of beam damage on the surface of the crystals after the electron microprobe analysis for $\mathrm{Cl}$ (Fig. 1).

\section{LA-ICP-MS}

Element concentrations of the crystalline phases and of the fluid solute trapped between the diamonds were analyzed by LA-ICP-MS at the Laboratory for Inorganic Chemistry, ETH Zürich, using a 193-nm ArF excimer laser system (Günther et al. 1997) coupled to an ELAN 6100 quadrupole ICP-MS. All elements except $\mathrm{Cl}$ were standardized against a NIST SRM610 glass, and a synthetic Cl-bearing basaltic glass (Fabbrizio et al. 2013) was used as standard for $\mathrm{Cl}$. The glass was analyzed two times before and two times after performing analyses of the samples of interest and served as external standard. $\mathrm{Na}$ was used as internal standard for the synthetic glass. Ba was used for internal standardization to calculate element concentration in the quenched fluid, by assuming that $\mathrm{Ba}$ (the most incompatible element in this study) partitions totally into the fluid phase.

Diamond traps (Fig. 1f) were measured with the laser imaged to $120 \mu \mathrm{m}$ diameter at repetition rates of $5 \mathrm{~Hz}$. Eight analyses were carried out on the diamond trap for each sample. In order to check the potential influence of mass interferences of ${ }^{23} \mathrm{Na}^{12} \mathrm{C}$ and ${ }^{35} \mathrm{Cl}$, both chlorine isotopes $\left({ }^{35} \mathrm{Cl}\right.$ and $\left.{ }^{37} \mathrm{Cl}\right)$ were measured. Since the differences in the isotope ratio were always below $3 \%$, the influence of this interference was considered negligible. The detection limit for chlorine was below 100 ppm. For minerals analysis, the NIST SRM610 glass was used to calibrate elements. Element concentration calculations were based on the Si concentration as determined by electron microprobe analysis. For the analysis of the crystalline phases, the diameter of the laser was adjusted as function of the crystal size (Fig. 1b, d); in general, beam diameters of $50-120 \mu \mathrm{m}$ were used at repetition rates of $5 \mathrm{~Hz}$.

\section{IR spectroscopy}

All experimental charges were cut as whole capsule by a diamond wire saw to preserve the texture, and then, double-sided polished wafers of $150 \mu \mathrm{m}$ thickness were prepared. Sample thicknesses were measured using a Mitutoyo micrometer and are accurate to $\pm 2 \mu \mathrm{m}$. In order to evaluate the orientation of the measured olivine crystals, reference spectra on oriented olivine crystals from Stöppling/Germany (Oehm et al. 1983) were recorded that were later compared with the olivine spectra of the experimental charges (Fig. 2).

IR spectra were recorded at room temperature in transmission mode using a Bruker Vertex 70 FTIR 
Fig. 1 BSE images of a sample Cl-26, b sample $\mathrm{Cl}-26$ with laser ablation spots in the crystalline phases, c sample $\mathrm{Cl}-24$, d sample $\mathrm{Cl}-24$ with laser ablation spots in the crystalline phases, e sample $\mathrm{Cl}-\mathrm{F}-1$, the one investigated by TEM,

f diamond trap of sample $\mathrm{Cl}-22$ after laser ablation analysis. The circular holes are laser ablation pits now filled by epoxy. Ol olivine (dark gray), opx orthopyroxene (medium gray), cpx clinopyroxene (light gray), amph amphibole (lighter gray), en enstatite (light gray), fo forsterite (dark gray), $q F l$ quenched fluid

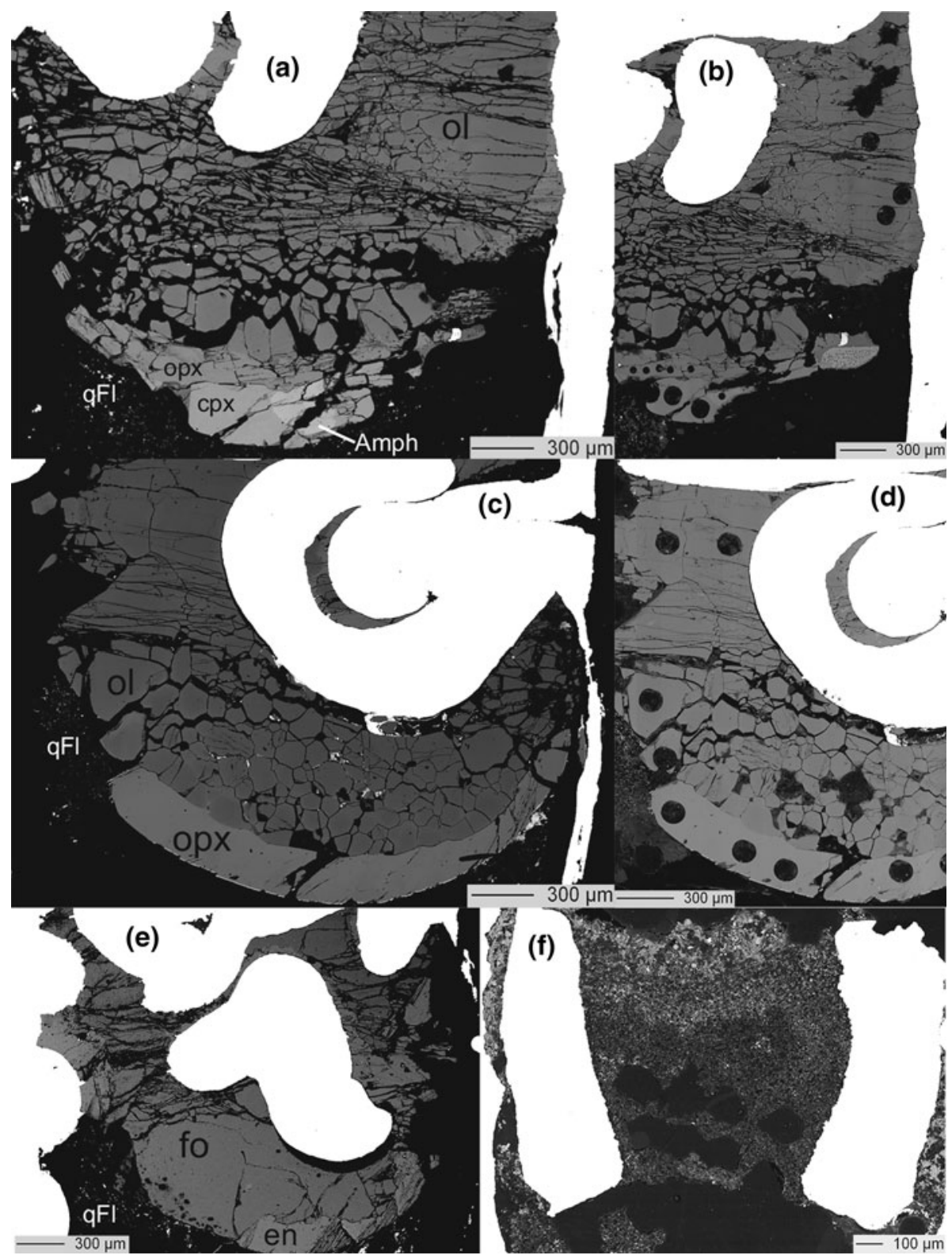

spectrometer, which was continuously flushed with dried air to minimize water-vapor background, coupled to a Hyperion 3000 microscope equipped with (1) a usual nitrogen-cooled MCT-D316-025 (mercury cadmium telluride) detector (in the following called single-element detector) and (2) a nitrogen-cooled focal plane array (FPA) detector consisting of $64 \times 64$ MCT-D364 detectors. For measurements with the single-element detector, each spectrum was acquired by 64 scans in the $550-7,500 \mathrm{~cm}^{-1}$ range with a spectral resolution of $2 \mathrm{~cm}^{-1}$. The FPA detector enables FTIR imaging of an area measuring $170 \times 170 \mu \mathrm{m}$ with a lateral pixel resolution of $2.7 \mu \mathrm{m}$. For each spectrum, 64 scans in the $850-3,950 \mathrm{~cm}^{-1}$ range were acquired with a spectral resolution of $4 \mathrm{~cm}^{-1}$. Selected spectral ranges were integrated automatically for all spectra, and the results were color-coded and graphically displayed as a map that was used as overview for measurements with the IR single-element detector masked with apertures of typically $50 \times 50 \mu^{2}$. Grain boundaries and areas on the crystal, which are penetrated by cracks or inclusions, could be easily detected and avoided as analysis area for IR measurements. From each capsule and on each wafer, unpolarized spectra of 10-15 randomly oriented olivine single crystals were recorded and averaged.

\section{TEM}

In order to check whether $\mathrm{F}$ in olivine is incorporated by F-clinohumite lamellae (Stalder and Ulmer 2001), 
Fig. 2 Polarized IR spectra of olivine sections parallel to $\alpha, \beta$, $\gamma$ and average spectrum $(\alpha+\beta+\gamma) / 3$. Unpolarized IR spectra of olivine averaged over 10-15 randomly oriented crystals from the $\mathrm{MSH}+\mathrm{F} \pm \mathrm{TiO}_{2}$ system

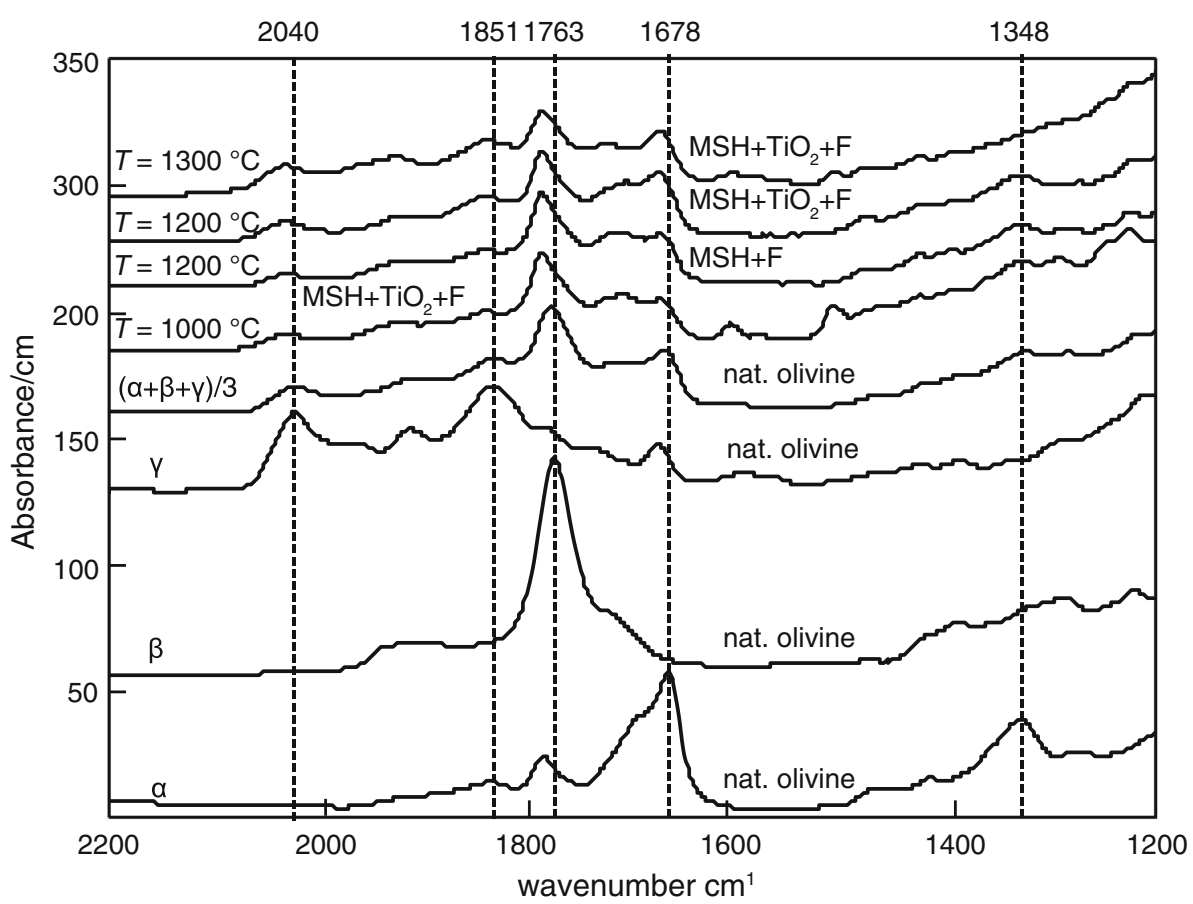

transmission electron microscopy (TEM) was carried out on a forsterite of run Cl-F-1 using a FEI Tecnai $\mathrm{G}^{2} \mathrm{~F}^{20}$ $\mathrm{X}$-Twin transmission electron microscope at GeoForschungsZentrum Potsdam, Germany, operated at $200 \mathrm{kV}$. Selected area electron diffraction (SAED), combined with bright field (BF), high-resolution (HR-TEM) and scanning transmission electron microscopy using a high-angle annular dark field detector in scanning transmission mode (STEM-HAADF), was performed to investigate the local defect structure of forsterite. The sample for TEM was prepared by first determining the orientation of the olivine using electron-backscattered diffraction (EBSD) with an Ultra 55 Plus (Carl Zeiss SMT) field emission scanning electron microscope. The foil for TEM was prepared by the focused ion beam technique (FIB) (Wirth 2004; Lee et al. 2003; Phaneuf 1999) using a FEI FIB200TEM focused ion beam device. After cutting the foil to the dimensions of $12 \times 8 \mu \mathrm{m}^{2}$ and a thickness of about $100 \mathrm{~nm}$, the foil was extracted from the excavation site using the lift-out technique (Giannuzzi et al. 1997). It was transferred to a copper TEM grid with a holey carbon foil to sustain the TEM foil using a manipulator.

\section{Results}

Textures of minerals and diamond traps

Experimental conditions and results are summarized in Tables 1, 2 and 3 and in the Online Resource 1. Since one of the aims of this study was the determination of mineral/ fluid partition coefficients, it is important to judge whether crystals grew subsolidus (and consequently the term 'fluid' can be used) or supersolidus, i.e., in the presence of a hydrous melt. The simple system forsterite-enstatite-water approaches melting at $1,400{ }^{\circ} \mathrm{C}$ and $2 \mathrm{GPa}$ (Kushiro and Yoder 1969); however, the presence of $\mathrm{NaCl}$ suppresses melting because it lowers the water activity (Aranovich and Newton 1996, 1997; Shmulovich and Graham 1996). A Cl/ $\left(\mathrm{Cl}+\mathrm{H}_{2} \mathrm{O}\right)$ molar ratio of 0.2 and 0.4 increases the temperature of the solidus in the system $\mathrm{Mg}_{2} \mathrm{SiO}_{4}+\mathrm{Mg}$ $\mathrm{SiO}_{3}+\mathrm{H}_{2} \mathrm{O}+\mathrm{KCl}$ at $5 \mathrm{GPa}$, respectively, of $\sim 200$ and $\sim 350{ }^{\circ} \mathrm{C}$ (Chu et al. 2011). Consequently, since the experiments reported here have a $\mathrm{Cl} /\left(\mathrm{Cl}+\mathrm{H}_{2} \mathrm{O}\right)$ molar ratio of 0.3 , they can be considered being subsolidus. The textures of the experimental charges can serve as additional constraint of the absence of a melt during the runs. Textures of representative run products are shown in Fig. 1. No particular textural differences are noted between experiments performed at different temperatures (Fig. 1a-e). Phases interpreted to have crystallized in equilibrium with each other in the absence of a melt are euhedral to subhedral and typically have the same grain size. The quenched phase is subhedral and typically displays acicular habit. The small amount of quench phase (Fig. 1a-e) is interpreted to represent the solute quenched from the subsolidus fluid phase. No abrupt increase in the amount of quenched phase with temperature was observed, which is interpreted to indicate the absence of a melt in all performed experiments. 
Phase assemblages

Run products were mainly composed of olivine, pyroxenes, salt and aqueous fluid. In single cases, additional phases such as clinohumite, amphibole or spinel were observed. Individual phase assemblages are listed in Table 1. The size of the crystals varied between 80 and $300 \mu \mathrm{m}$ in the natural system and was over $300 \mu \mathrm{m}$ in the MSH system (Fig. 1). Electron microprobe analyses are listed in the Online Resource 1 and in Table 2. No chemical zoning patterns were observed. In the experiments with the natural composition, only olivine $\left(\mathrm{Fo}_{97}\right)$ is present at temperature above $1,100{ }^{\circ} \mathrm{C}$, at $1,100{ }^{\circ} \mathrm{C}$ orthopyroxene appears, at $1,000{ }^{\circ} \mathrm{C}$ olivine coexists with ortho- and clinopyroxene and at $900{ }^{\circ} \mathrm{C}$ amphibole occurred in addition. Spinel coexists with olivine in the run buffered by the reaction $\mathrm{Fe}-\mathrm{FeO}$. The $\mathrm{Cl}$ concentrations in olivine are $20 \pm 14 \mathrm{ppm}$, in opx $26 \pm 10$ ppm and in cpx $20 \pm 4$ ppm, whereas the $\mathrm{Cl}$ contents of amphibole is $585 \pm 36 \mathrm{ppm}$.

In the synthetic system, forsterite $\left(\mathrm{Fo}_{100}\right)$ coexists with enstatite in all runs. At $1,200{ }^{\circ} \mathrm{C}$, clinohumite coexists with forsterite and enstatite and at $1,000{ }^{\circ} \mathrm{C}$ F-tremolite (4.2 wt\% F), diopside $\left(\mathrm{Di}_{85} \mathrm{En}_{15}\right.$ containing $690 \mathrm{ppm} \mathrm{F}$ ) and an unidentified F-bearing phase-supposedly talc-

Table 2 Analyses of the run products (model system and natural peridotite) by EMPA

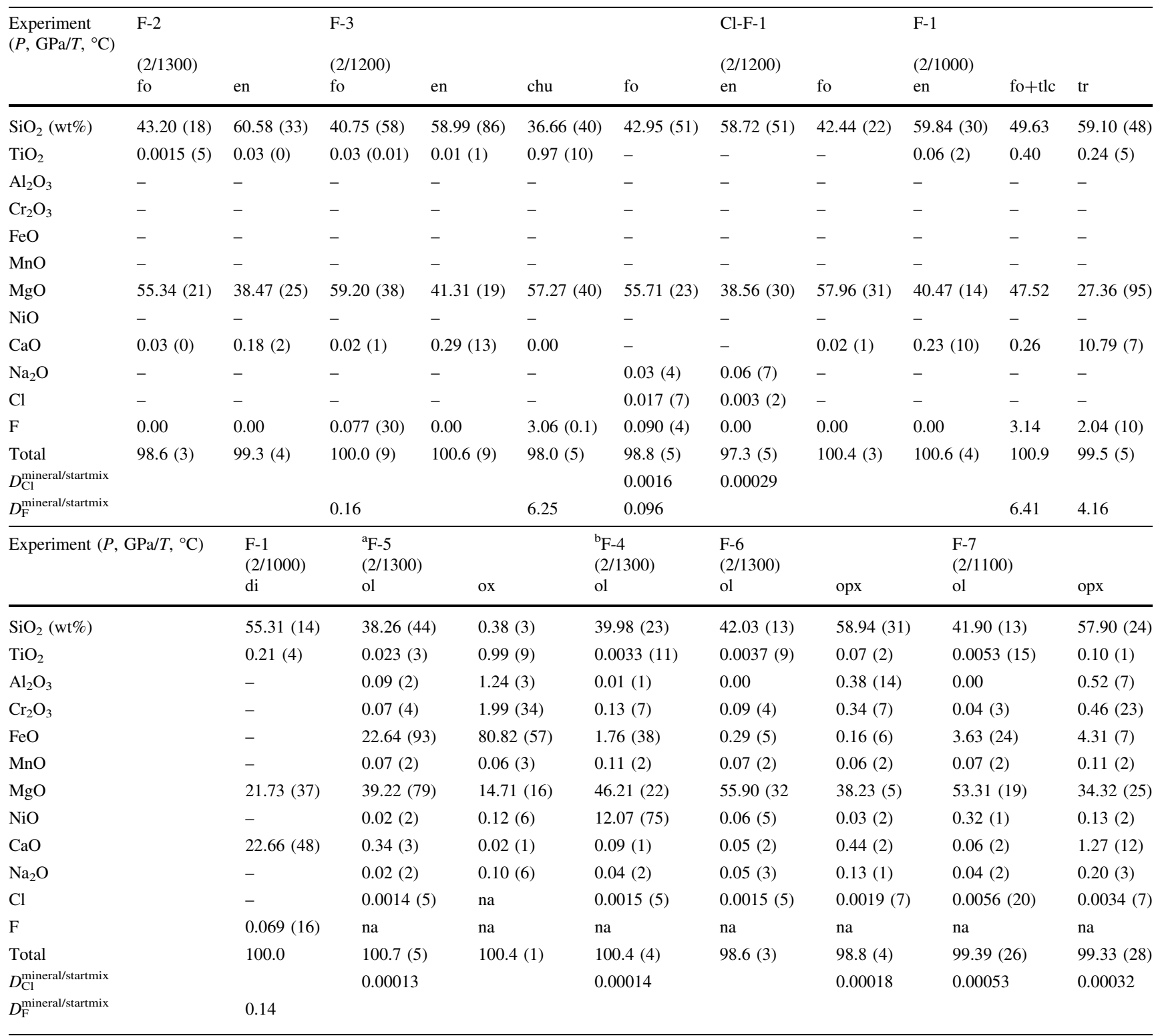

a Capsule lined with Fe foil

b Capsule lined with Ni foil 


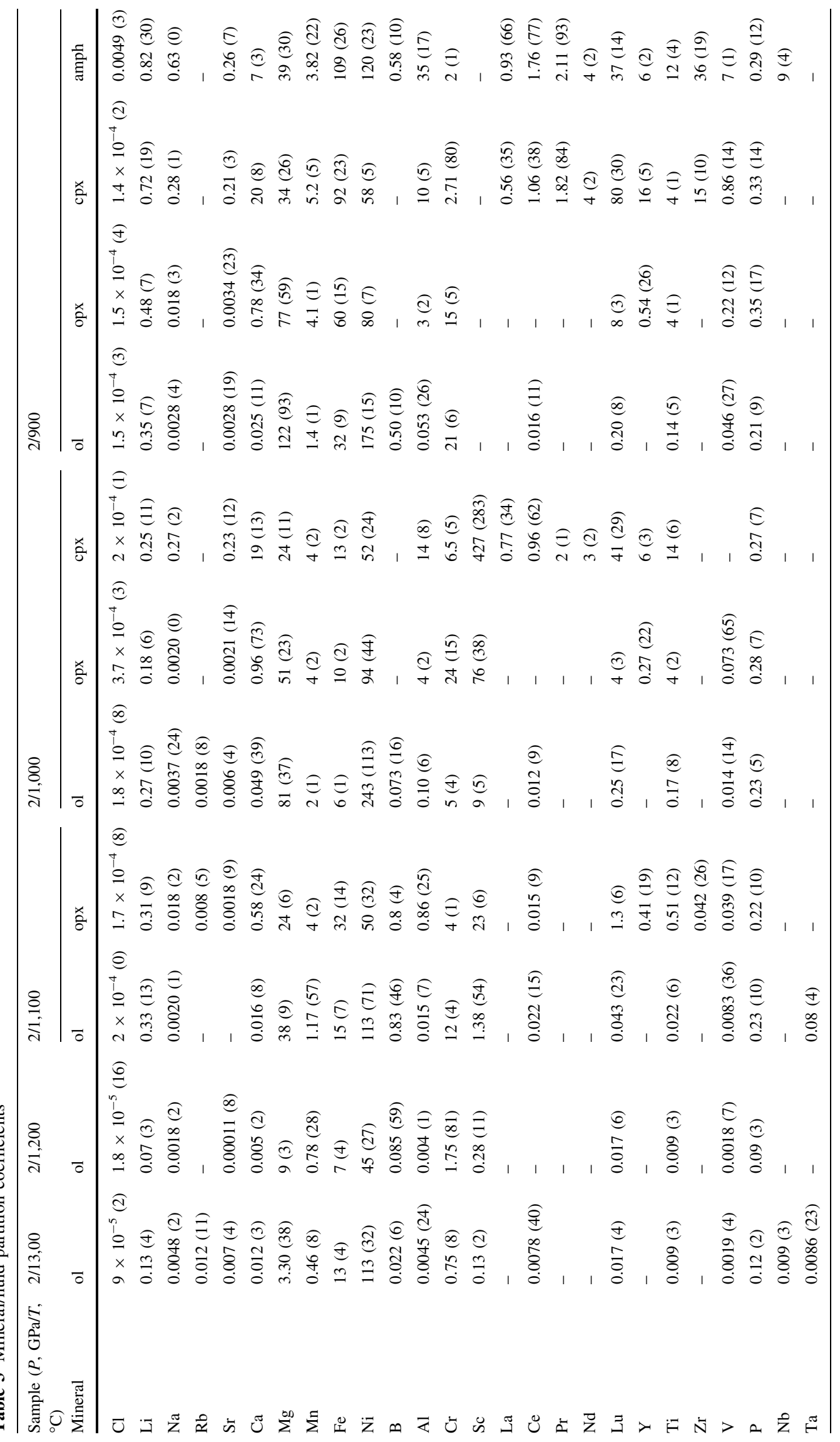


occurred. At $1,200{ }^{\circ} \mathrm{C}$, forsterite has a $\mathrm{F}$ content of $900 \pm 40 \mathrm{ppm}$ and a $\mathrm{Cl}$ content of $170 \pm 70 \mathrm{ppm}$. Enstatite shows a $\mathrm{Cl}$ content of $30 \pm 20 \mathrm{ppm}$, similar to the opx in the run with natural starting composition. The aqueous fluids are homogeneous with respect to their major element composition. Most trace elements were below detection limit both in minerals and in the quenched solute. Concentrations measured with LA-ICP-MS and calculated partition coefficients (mineral/fluid) are illustrated in Fig. 3 and listed in the Online Resource 1 and in Table 3.

\section{Fluid compositions}

The compositions of the aqueous fluids were determined with LA-ICP-MS (Online Resource 1). The aqueous fluids of each run are homogenous with respect to their major element composition and contain large amount of silicate components (mainly $\mathrm{Si}, \mathrm{Mg}, \mathrm{Al}, \mathrm{Ca}, \mathrm{Na}$ and $\mathrm{Cl}$ ). Measured fluid compositions are generally consistent from run to run with the temperature of the run.

The plot of the $\mathrm{MgO} / \mathrm{SiO}_{2}$ molar ratios of the fluids versus the temperature of the runs (Fig. 4) shows a positive correlation, probably reflecting a decreased solubility of silica with temperature.

\section{Mineral/fluid partition coefficients}

Mineral/fluid partition coefficients (Fig. 3) show that $\mathrm{Cl}$ and the large ionic lithophile elements (LILE) always partition into the fluid phase, whereas most other trace elements behave compatible in clinopyroxene and amphibole, moderately incompatible to compatible in orthopyroxene and incompatible in olivine (Fig. 3). These findings, specifically the order $D^{\text {amph/fluid }} \approx D^{\text {cpx/fluid }}>D^{\text {opx/fluid }}$ $>D^{\text {ol/fluid }}$, is in general agreement with previous studies (Mysen 1979; Brenan et al. 1995; Ayers et al. 1997; Stalder et al. 1998; Caciagli et al. 2011; Fabbrizio et al. 2013). In contrast, $D^{\text {mineral/fluid }}$ is very similar for $\mathrm{Li}$ and $\mathrm{P}$ for all observed silicate phases.

Measured olivine/fluid partition coefficients show that olivine strongly depletes $\mathrm{Cl}, \mathrm{Na}, \mathrm{Ce}$ and $\mathrm{Sr}$ relative to the fluid (Fig. 3), with low values for $\mathrm{Cl} \sim 10^{-4}$, intermediate values for $\mathrm{Na}$ and $\mathrm{Sr}\left(\sim 10^{-3}\right)$ and higher values for $\mathrm{Ce}$ $\left(\sim 10^{-2}\right)$. Olivine/fluid values for $\mathrm{Li}, \mathrm{B}, \mathrm{Ti}, \mathrm{Lu}, \mathrm{V}$ and $\mathrm{P}$ are $\sim 10^{-1}$.

Orthopyroxene/fluid values (Fig. 3) are given as follows: $\mathrm{Cl} \sim 10^{-4}, \mathrm{Sr} \sim 10^{-3}, \mathrm{Na}$ and $\mathrm{Ce} \sim 10^{-2}, \mathrm{Li}, \mathrm{Y}, \mathrm{V}$ and $\mathrm{P} \sim 10^{-1}$, Ti and $\mathrm{Lu} \sim 5$.

Clinopyroxene/fluid partition coefficients show a strong enrichment of $\mathrm{Pr}, \mathrm{Nd}, \mathrm{Zr}, \mathrm{Ti}, \mathrm{Y}$ and $\mathrm{Lu}$ in clinopyroxene relative to the fluid (Fig. 3), with values for $\mathrm{Lu} \sim 10^{2}$, for $\mathrm{Ti}, \mathrm{Y}, \mathrm{Nd}, \mathrm{Pr}$ and $\mathrm{Zr}$ in the range 1-10. Clinopyroxene/fluid

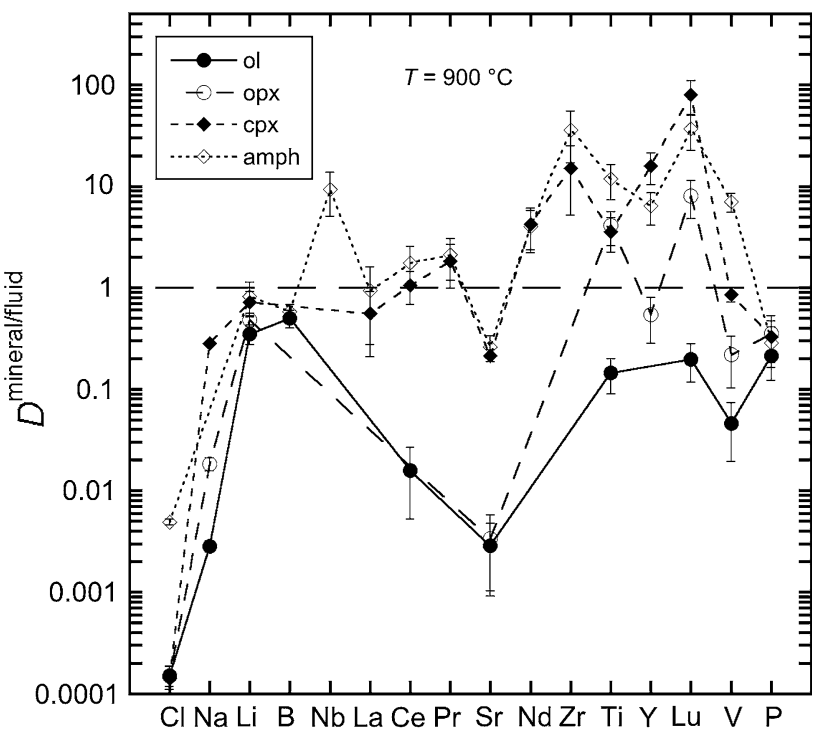

Fig. 3 Representative mineral/fluid partition coefficients for coexisting minerals from experiments $\mathrm{Cl}-26$. The horizontal dashed line represent the limit between compatibility $\left(D^{\text {mineral/fluid }}>1\right)$ and incompatibility $\left(D^{\text {mineral/fluid }}<1\right)$

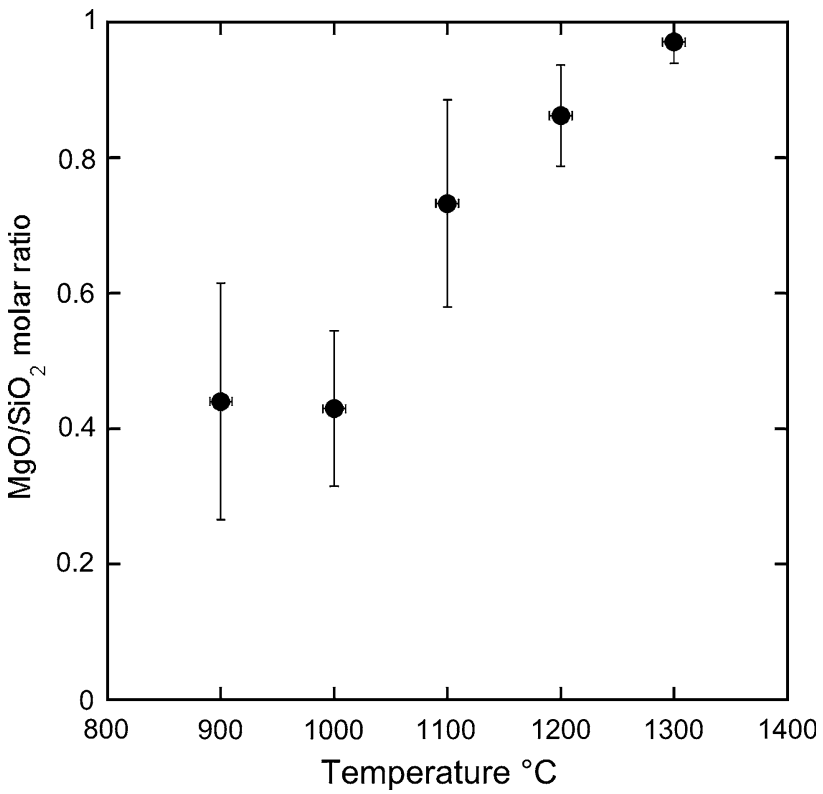

Fig. $4 \mathrm{MgO} / \mathrm{SiO}_{2}$ molar ratio of the fluids calculated from the LAICP-MS analyses (Online Resource 1) versus the temperature $\left({ }^{\circ} \mathrm{C}\right)$ of the runs

values for $\mathrm{Na}, \mathrm{Li}, \mathrm{La}, \mathrm{Sr}, \mathrm{V}$ and $\mathrm{P}$ are in the range $10^{-1}-1$ and for $\mathrm{Cl}$ are $\sim 10^{-4}$.

Amphibole is enriched in $\mathrm{Nb}, \mathrm{Ce}, \mathrm{Pr}, \mathrm{Nd}, \mathrm{Zr}, \mathrm{Ti}, \mathrm{Y}$, $\mathrm{Lu}$ and $\mathrm{V}$ with respect to the fluid with amphibole/fluid values larger than 1 (Fig. 3). Amphibole/fluid values are in the range $\sim 10^{-1}-1$ for $\mathrm{Li}, \mathrm{B}, \mathrm{La}, \mathrm{Sr}, \mathrm{P}$ and $\sim 5 \times$ $10^{-3}$ for $\mathrm{Cl}$. 
One important factor controlling olivine-fluid trace element partitioning is the solute content of the fluid phase (Fig. 5). As observed in previous studies (Stalder et al. 2001; Kessel et al. 2004), the total solute content is positively correlated with temperature (Online Resource 1) concomitant with a decrease in $D^{\text {ol/fluid }}$. This trend is extremely pronounced for some cations (e.g., Ti), with $D^{\text {ol/fluid }}$ dropping by $1-2 \log$ units as the solute content increases to a similar extent. Similar effects on $D^{\text {mineral/fluid }}$ were reported by Brenan and Watson (1991) and Brenan et al. (1995).

\section{$\mathrm{Cl}$ and $\mathrm{F}$ partition coefficients}

$\mathrm{Cl}$ mineral/fluid partition coefficients $\left(D_{\mathrm{Cl}}\right)$ were calculated from the $\mathrm{Cl}$ concentration in the mineral measured by EMPA and the $\mathrm{Cl}$ concentration of the coexisting fluid measured by LA-ICP-MS. The $D_{\mathrm{Cl}}^{\mathrm{ol} / \mathrm{fl}}$ is between $9 \times 10^{-5}$ and $2 \times 10^{-4}$. Chlorine in orthopyroxene is more compatible than in olivine with $D_{\mathrm{Cl}}^{\text {opx/fl }}$ values between $1.5 \times 10^{-4}$ and $3.7 \times 10^{-4}$. Clinopyroxene has $D_{\mathrm{Cl}}^{\mathrm{cpx} / \mathrm{fl}}$ values of $1.4 \times 10^{-4}$ and $2 \times 10^{-4}$ similar to orthopyroxene, and amphibole shows the highest $D_{\mathrm{Cl}}^{\mathrm{amph} / \mathrm{fl}}$ value of $4.9 \times 10^{-3}$. For fluorine and for runs performed without diamond trap, the partition coefficients can be estimated as the ratio between the concentration in mineral versus the concentration in the starting mixture. We obtain $D_{\mathrm{F}}^{\mathrm{fo} / \text { startmix }}$ $\sim 0.1$ for forsterite characterized by the presence of humite-type point defects, $D_{\mathrm{F}}^{\text {chu/startmix }}=6.25$ and $D_{\mathrm{F}}^{\mathrm{Di} / \text { startmix }}=0.14$ for diopsidic pyroxene (Table 2). The values for $D_{\mathrm{Cl}}^{\mathrm{ol} / \text { startmix }}$ are between $1.6 \times 10^{-3}$ and $5.3 \times 10^{-4}$ and that for $D_{\mathrm{Cl}}^{\text {opx } / \text { startmix }}$ vary between $1.8 \times 10^{-4}$ and $3.2 \times 10^{-4}$ in close agreement with the calculated partition coefficients.

IR spectra and IR images

Unpolarized IR spectra collected on olivine are shown in Fig. 6, and IR images that were recorded for visualization of the $\mathrm{OH}$ defects on the entire experimental charge are shown in Fig. 7.

Ti-bearing olivine crystals (Online Resource 1, Fig. 6), synthesized using the natural peridotite as starting material, exhibit absorption bands at 3,326, 3,354, 3,525, 3,571 and $3,612 \mathrm{~cm}^{-1}$. Olivine from the natural F-doped peridotite (Table 2; Fig. 6) displays also the absorption band at $3,535,3,595,3,640$ and $3,670 \mathrm{~cm}^{-1}$, and the band at $3,570 \mathrm{~cm}^{-1}$ tends to become stronger (i.e., higher intensity). Olivine crystallized under relatively oxidizing conditions $\left(f \mathrm{O}_{2}=\mathrm{QFM}+1.5\right)$ shows an IR spectrum similar to that of olivine crystallized with no constrain on $\mathrm{fO}_{2}$, whereas the IR spectra of olivine crystallized under

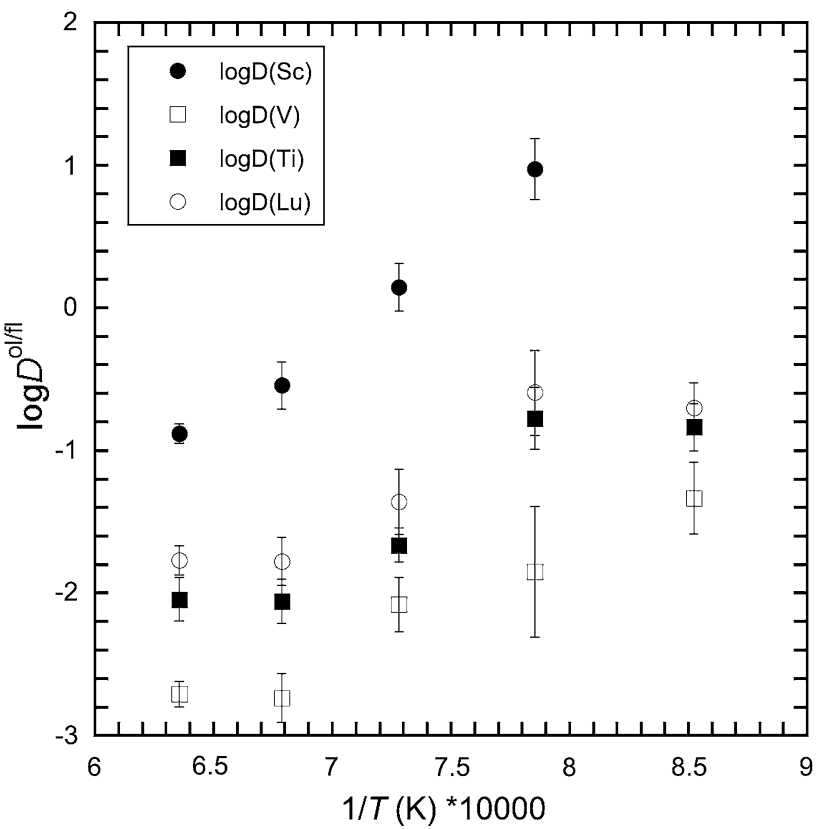

Fig. 5 Partition coefficients $\log D^{\text {ol/fluid }}$ for some trace elements as function of the inverse temperature $(\mathrm{K})$

reducing conditions $\left(f \mathrm{O}_{2}=\mathrm{QFM}-3\right)$ do not have bands at 3,326 and $3,354 \mathrm{~cm}^{-1}$ and those over $3,500 \mathrm{~cm}^{-1}$ tend to be less intense. This observation supports the idea that the bands around $3,350 \mathrm{~cm}^{-1}$ can be assigned to $\mathrm{Fe}^{3+}$. related $\mathrm{OH}$ defects (Berry et al. 2007) and that olivine grown at low $\mathrm{fO}_{2}$ (below the $\mathrm{Fe}-\mathrm{FeO}$ ) contains much less water with respect to crystals from relatively more oxidized experiments (Grant et al. 2007b). Forsterite from the F-bearing model system (Table 2; Fig. 6) displays the strongest absorption bands at wavenumber similar to those for olivine from the natural peridotite plus $\mathrm{F}$ system. The main absorption bands are located at 3,569 and $3,536 \mathrm{~cm}^{-1}$, and the bands above $3,590 \mathrm{~cm}^{-1}$ are more intense with respect to the bands for olivine from the F-doped natural peridotite system. In addition, the bands at 3,326 and $3,354 \mathrm{~cm}^{-1}$ are absent. The thickness of the samples is comparable, and hence, the intensity of absorption is related to the amount of $\mathrm{OH}$. The observed spectra indicate that the presence of $\mathrm{F}$ in the system permits to incorporate much more $\mathrm{OH}$ in olivine compared with olivine from the Ti-bearing and F-free system.

IR images (Fig. 7) were recorded on the whole sample Cl-F-1 containing the fluorine-rich forsterite crystals (Table 2; Fig. 6). No absorption bands close to $3,400 \mathrm{~cm}^{-1}$ were detected, suggesting the absence or a very low abundance of humite-type planar defects (Hermann et al. 2007).

Additional data on the amounts of water dissolved in olivine are reported in the Online Resource 2. 
Fig. 6 Unpolarized IR spectra of olivine averaged over 10-15 randomly oriented crystals for each run. Spectra are normalized to $1 \mathrm{~cm}$ thickness. Vertical dashed lines indicate the positions of $\mathrm{OH}$ bands. Experimental run details are labeled above each spectrum

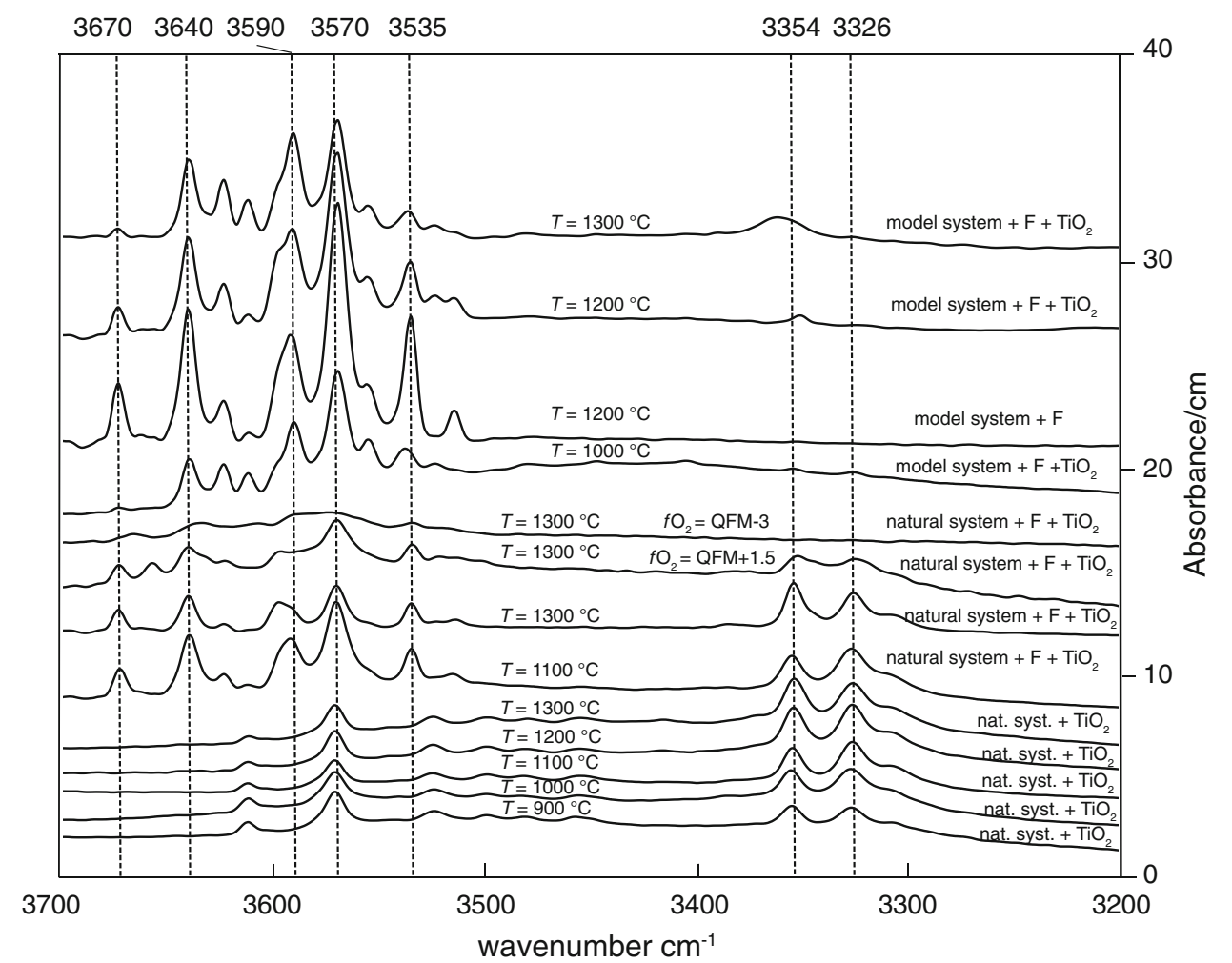

\section{TEM}

The analyzed TEM foils were cut from a forsterite crystal from sample $\mathrm{Cl}-\mathrm{F}-1$ with orientation $\sim$ [714] as determined by EBSD. This sample was chosen due to the high fluorine content of its forsterite (Table 2). The foils were cut after chemical polishing of the sample. Chemical polishing results in preferential material removal in regions with defects. Lamellar features that are approximately oriented in the direction expected for humite-type defects (parallel $(001)_{\mathrm{Ol}}$ ) are observed in the BSE image (Fig. 8a). Three TEM foils were cut, two across these features and one parallel, in order to determine its origin. Neither bright field TEM, nor HRTEM or STEM did show any chemical or structural variations in the investigated foils. As far as planar defects such as humitelamellae are concerned, selected area diffraction in [100], [110] or [010] should depict evidence in the form of streaks, as humite has significantly different lattice parameters to olivine, always assuming the presence of enough such lamellae. The streaks in the diffraction pattern would be perpendicular to the plane of their orientation. Thus, the effect should best be visible on (001) diffraction spots, examples are given in Hermann et al. (2007), Kitamura et al. (1987), Risold et al. (2001), and Wirth et al. (2001). No such streaks were observed. Instead of lamellae, dislocations were observed in the bright field image (Fig. 8b), indicating another type of defect hitherto not considered as potential repository for halogens and hydrogen. However, the absence of planar defects cannot be proved, but the concentration is certainly rather low in this sample. Considering the fluorine content of the analyzed forsterite $(0.09 \mathrm{wt} \% \mathrm{~F})$ and the ideal fluorine content in stoichiometric F-clinohumite $(6.1 \mathrm{wt} \% \mathrm{~F})$, the hypothetical fraction of F-clinohumite hosted in the forsterite lattice is approximately $1.5 \%$, corresponding to $0.34 \mathrm{~mol} \%$ clinohumite in forsterite. For TEM observations, this would mean that only 1 out of $300 \mathrm{~d}$-spacing perpendicular to the lamellae would appear broader.

\section{Discussion}

Halogen partitioning and major hosts for halogens in the mantle

Our single data point from experiment crystallizing forsterite with clinohumite defects gives $D_{\mathrm{ol}}^{\mathrm{F} / \mathrm{Cl}}=5.3$, in agreement with the general observation that $\mathrm{F}$ is less incompatible than $\mathrm{Cl}$ in olivine (e.g., $D_{\mathrm{ol}}^{\mathrm{F} / \mathrm{Cl}}$ values between 0.9 and 13 Hauri et al. 2006; Beyer et al. 2012; Dalou et al. 2012). Our results for chlorine partitioning between mantle minerals and coexisting aqueous fluid (Table 3 ) are in good agreement with results from the system forsterite-enstatite-pyrope- $\mathrm{H}_{2} \mathrm{O}-\mathrm{MgCl}_{2}$ at $1,100{ }^{\circ} \mathrm{C}$ and $2.6 \mathrm{GPa}$ (Bernini 


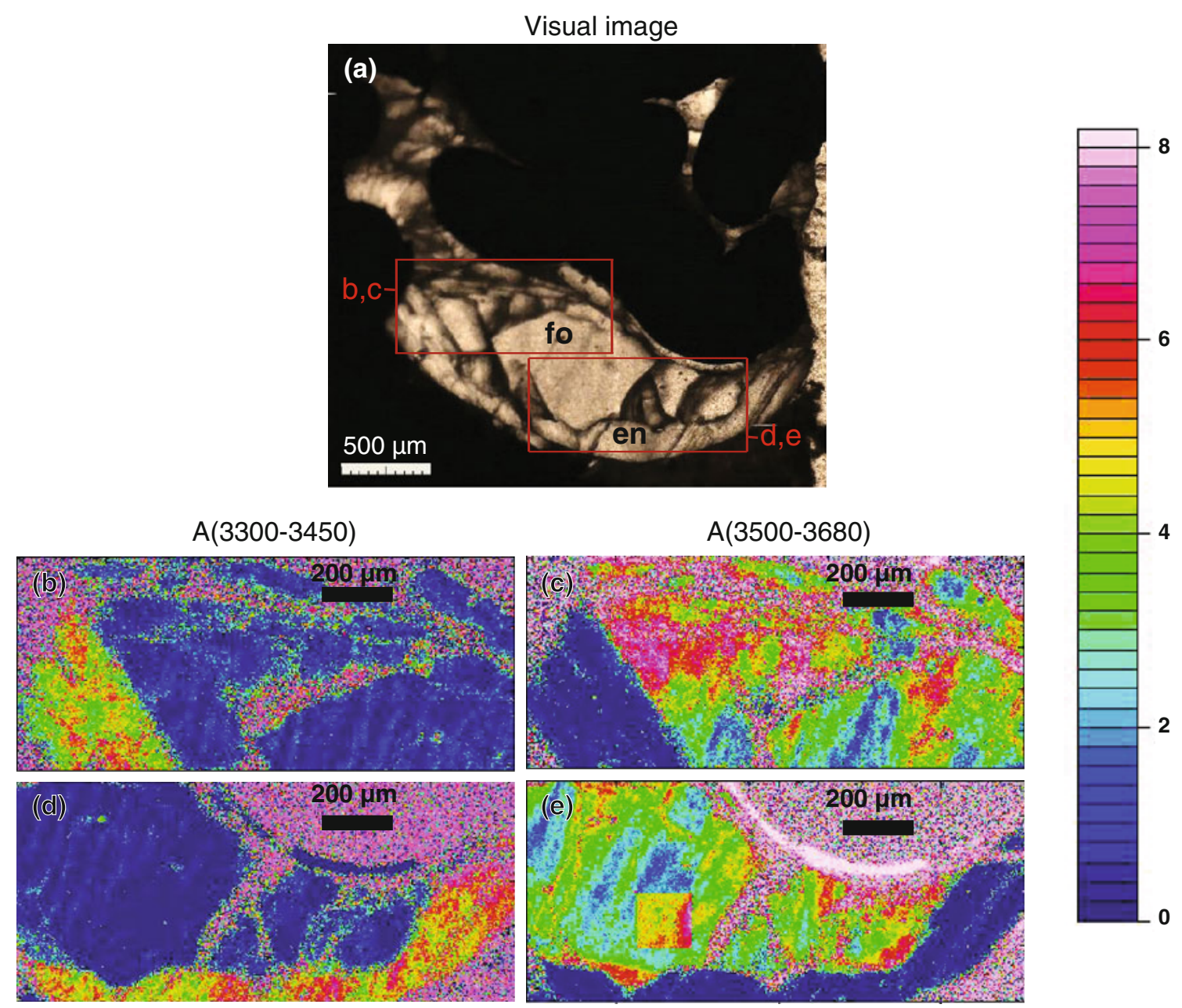

Fig. 7 Visual image a of sample Cl-F-1, b-e IR images displaying total absorbances in the wavenumber range (see color code right) $\mathbf{b}$, d $3,300-3,450 \mathrm{~cm}^{-1}$ and c, e 3,500-3,680 $\mathrm{cm}^{-1}$ color-coded according to the scale bar to the right (not normalized to thickness). Each pixel $\left(2.7 \times 2.7 \mu \mathrm{m}^{2}\right)$ contains the full information of an IR spectrum and can be extracted separately. Note the absence of any band close to
$3,400 \mathrm{~cm}^{-1}$ indicating the absence of humite-type planar defects (Hermann et al. 2007). The rectangular feature left to the center in (e) represents one $170 \times 170 \mu \mathrm{m}^{2}$ frame. Compared to the surrounding frames, it exhibits enhanced absorbance interpreted as analytical artifact probably caused by an electric spike during data acquisition

or chlorite. Taking into account the modal proportions in the mantle and estimations for the total halogen content (Saal et al. 2002), olivine may be regarded as an important host for halogens in the Earth's mantle.

Incorporation mechanism of halogens into nominally halogen-free minerals

In analogy to $\mathrm{OH}$ incorporation in olivine, two different groups of defects can be encountered for halogen incorporation in olivine: point defects (Berry et al. 2005, 2007) and planar defects (Kitamura et al. 1987; Hermann et al. 2007). Both groups of defects permit to incorporate $\mathrm{OH}$ in the forsterite structure and thus can serve as host for halogens by permitting a direct exchange between halogens and $\mathrm{OH}$. Planar defects are more likely close to the clinohumite 

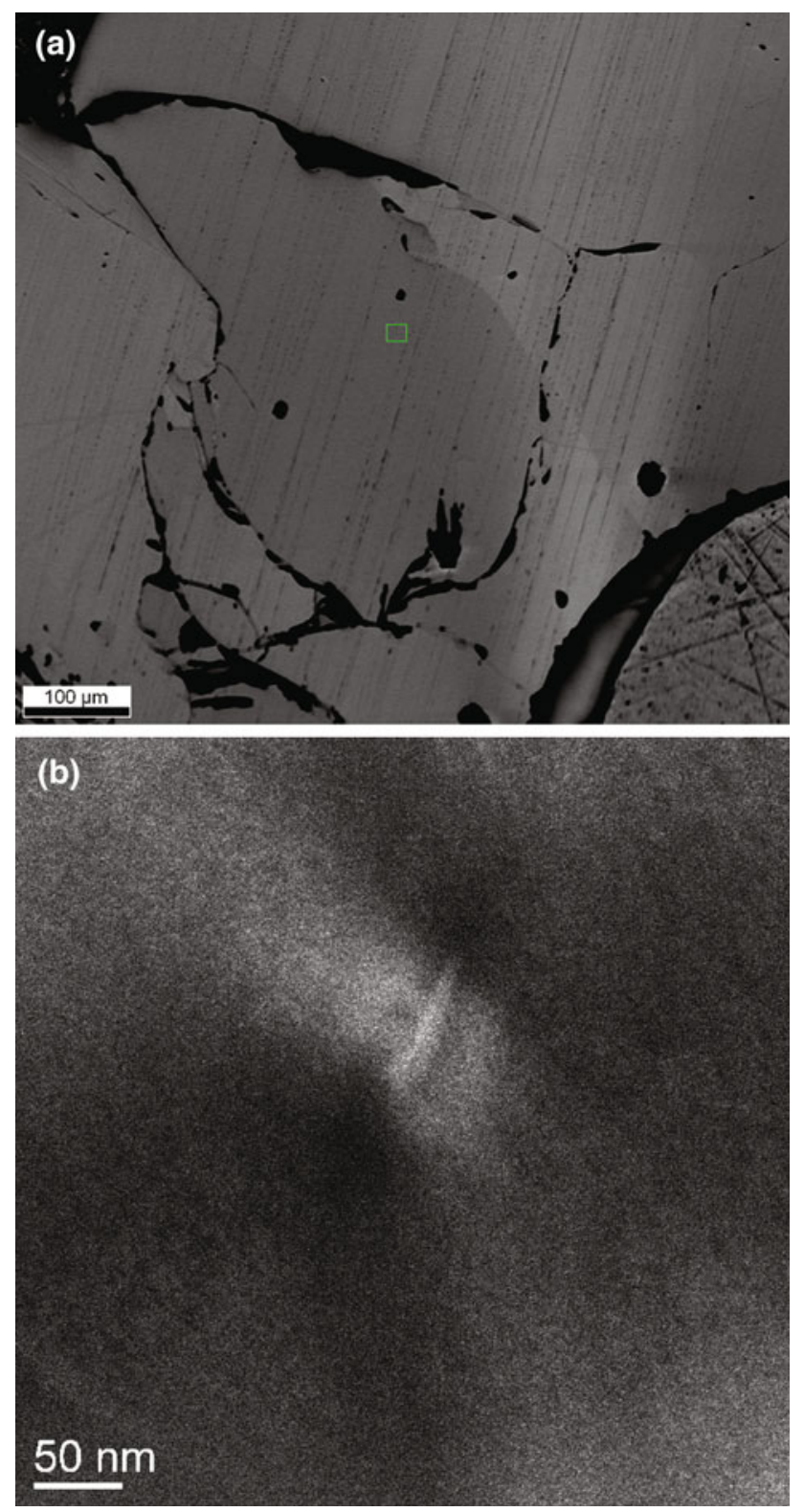

Fig. 8 a Backscattered electron image of sample CL-F-1 showing lamellar features in the olivine crystals. The rectangle in the center depicts one of the regions from where EBSD measurements were taken. b Bright field image showing a dislocation in the olivine crystal

breakdown curve that depends on the $P-T-X$ conditions (Weiss 1997; Ulmer and Trommsdorff 1999), but at conditions far above the clinohumite breakdown, $\mathrm{OH}$ and halogen incorporation is dominated by point defects (Hermann et al. 2007). Olivine IR absorption bands have been related to the type of defect permitting thus to distinguish between point and planar defects. IR absorption bands at 3,525 and $3,572 \mathrm{~cm}^{-1}$ have been assigned to humite-type point defects (Berry et al. 2005), whereas band at $\sim 3,400 \mathrm{~cm}^{-1}$ is related to humite-type planar defects (Hermann et al. 2007). IR spectra recorded on $\mathrm{F} \pm$ Ti-bearing olivine (Fig. 6) reveal strong absorption bands at 3,535 and $\sim 3,570 \mathrm{~cm}^{-1}$, and no absorption band close to $3,400 \mathrm{~cm}^{-1}$ is revealed in the IR spectra of the same crystals and in the IR images (Fig. 7) of the fluorine-rich forsterite investigated by TEM, suggesting the presence of humite-type point defects instead of humitetype planar defects. Note that the bands at 3,535 and $\sim 3,570 \mathrm{~cm}^{-1}$ tend to be less intense for F-free Ti-bearing olivine and for olivine coexisting with F-bearing minerals, whereas they tend to become more intense in the F-bearing systems at lower temperature. These observations suggest that in the F-Ti-bearing system, lower temperatures tend to promote the stabilization of point defects in olivine. In the olivine crystal investigated by TEM, no indications for humite-lamellae were found. This observation is in accord with the IR spectrum and images recorded on the same crystal, where no absorption bands around $3,400 \mathrm{~cm}^{-1}$ were detected, and-considering the relatively high synthesis temperature of $1,200{ }^{\circ} \mathrm{C}$ - the predominance of point defects was actually expected (Hermann et al. 2007). However, the observation of a dislocation may suggest that the concept of different defect regimes in the $P-T-X$-space is more complex than previously elaborated. It may be speculated that between the regimes of planar defects (at temperatures just above the clinohumite breakdown, Hermann et al. 2007) and point defects (far above clinohumite breakdown), a defect regime where dislocations prevail may exist.

Acknowledgments This project was supported with a Lise Meitner grant to A.F. by the Austrian Science Fund (FWF): [M1266-N21]. We thank Martina Tribus for her assistance with electron microprobe analyses and Hannes Witting and Fabian Höpperger from the mechanical workshop for manufacturing the high-pressure assemblies for the experiments. Richard Tessadri is thanked for performing the XRD analysis. We thank two anonymous reviewers for constructive comments.

Open Access This article is distributed under the terms of the Creative Commons Attribution License which permits any use, distribution, and reproduction in any medium, provided the original author(s) and the source are credited.

\section{References}

Aerts M, Hack AC, Reusser E, Ulmer P (2010) Assessment of the diamond-trap method for studying high-pressure fluids and melts and an improved freezing stage design for laser ablation ICP-MS analysis. Am Mineral 95:1523-1526

Aiuppa A, Baker DR, Webster JD (2009) Halogens in volcanic systems. Chem Geol 263:1-18

Aranovich LY, Newton RC (1996) $\mathrm{H}_{2} \mathrm{O}$ activity in concentrated $\mathrm{NaCl}$ solutions at high pressures and temperatures measured by the brucite-periclase equilibrium. Contrib Mineral Petrol 125:200 212

Aranovich LY, Newton RC (1997) $\mathrm{H}_{2} \mathrm{O}$ activity in concentrated $\mathrm{KCl}$ and $\mathrm{KCl}-\mathrm{NaCl}$ solutions at high pressures and temperatures 
measured by the brucite-periclase equilibrium. Contrib Mineral Petrol 127:261-271

Ayers JC, Dittmer SK, Layne GD (1997) Partitioning of elements between peridotite and $\mathrm{H}_{2} \mathrm{O}$ at $2.0-3.0 \mathrm{GPa}$ and $900-1100{ }^{\circ} \mathrm{C}$, and application to models of subduction zone processes. Earth Planet Sci Lett 150:381-398

Baker DR, Balcone-Boissard E (2009) Halogen diffusion in magmatic systems: our current state of knowledge. Chem Geol 263:82-88

Bell DR, Rossman GR (1992) Water in Earth's mantle the role of nominally anhydrous minerals. Science 255:1391-1397

Bernini D, Wiedenbeck M, Dolejš D, Keppler H (2013) Partitioning of halogens between mantle minerals and aqueous fluids: implications for the fluid flow regime in subduction zones. Contrib Mineral Petrol 165:117-128

Berry AJ, Hermann J, O’Neill HSC, Foran GJ (2005) Fingerprinting the water site in mantle olivine. Geology 33:869-872

Berry AJ, O'Neill HSC, Hermann J, Scott DR (2007) The infrared signature of water associated with trivalent cations in olivine. Earth Planet Sci Lett 261:134-142

Beyer C, Klemme S, Wiedenbeck M, Stracke A, Vollmer C (2012) Fluorine in nominally fluorine-free mantle minerals: experimental partitioning of $\mathrm{F}$ between olivine, orthopyroxene and silicate melts with implications for magmatic processes. Earth Planet Sci Lett 337-338:1-9

Brenan JM, Watson EB (1991) Partitioning of trace elements between olivine and aqueous fluids at high $P-T$ conditions: implications for the effect of fluid composition on trace elements transport. Earth Planet Sci Lett 107:672-688

Brenan JM, Shaw HF, Ryerson FJ, Phinney DL (1995) Mineralaqueous fluid partitioning of trace elements at $900{ }^{\circ} \mathrm{C}$ and 2.0 $\mathrm{GPa}$ : constraints on the trace element chemistry of mantle and deep crustal fluids. Geochim Cosmochim Acta 59:3331-3350

Bromiley DW, Kohn SC (2007) Comparisons between fluoride and hydroxide incorporation in nominally anhydrous and fluorinefree mantle minerals. Geochim Cosmochim Acta 71:A124

Caciagli N, Brenan JM, McDonough WF, Phinney D (2011) Mineralfluid partitioning of lithium and implications for slab-mantle interaction. Chem Geol 280:384-398

Carroll MR, Webster JD (1994) Solubilities of sulfur, noble gases, nitrogen, chlorine, and fluorine in magmas. Rev Mineral Geochem 30:231-279

Chu L, Enggist A, Luth RW (2011) Effect of $\mathrm{KCl}$ on melting in the $\mathrm{Mg}_{2} \mathrm{SiO}_{4}-\mathrm{MgSiO}_{3}-\mathrm{H}_{2} \mathrm{O}$ system at $5 \mathrm{GPa}$. Contrib Mineral Petrol 162:565-571

Dalou C, Koga KT, Shimizu N, Boulon J, Devidal J (2012) Experimental determination of $\mathrm{F}$ and $\mathrm{Cl}$ partitioning between lherzolite and basaltic melt. Contrib Mineral Petrol 163:591-609

Drury MR (1991) Hydration-induced climb dissociation of dislocations in naturally deformed mantle olivine. Phys Chem Miner 18: $106-116$

Fabbrizio A, Stalder R, Hametner K, Günther D (2013) Experimental chlorine partitioning between forsterite, enstatite and aqueous fluid at upper mantle conditions. Geochim Cosmochim Acta. doi:10.1016/j.gca.2013.05.026

Giannuzzi LA, Drown JL, Brown SR, Irwin RB, Stevie FA (1997) Focused ion beam milling and micromanipulation lift-out for site-specific cross-section TEM specimen preparation. In: Anderson R, Walck S (eds) Proceedings of the Materials Research Society: workshop on specimen preparation for TEM of materials IV, vol 480. Materials Research Society, Pittsburgh, pp 19-27

Grant K, Brooker RA, Kohn SC, Wood BJ (2007a) The effect of oxygen fugacity on hydroxyl concentrations and speciation in olivine: implications for water solubility in the upper mantle. Earth Planet Sci Lett 261:217-229
Grant K, Ingrin J, Lorand JP, Dumas P (2007b) Water partitioning between mantle minerals from peridotite xenoliths. Contrib Mineral Petrol 154:15-34

Günther D, Frischknecht R, Heinrich C, Kahlert H (1997) Capabilities of an argon fluoride $193 \mathrm{~nm}$ excimer laser for laser ablation inductively coupled plasma mass spectrometry microanalysis of geological materials. J Anal Atom Spectrom 12:939-944

Hauri EH, Gaetani GA, Green TH (2006) Partitioning of water during melting of the Earth's upper mantle at $\mathrm{H}_{2} \mathrm{O}$-undersaturated conditions. Earth Planet Sci Lett 248:715-734

Hermann J, Fitz Gerald JD, Malaspina N, Berry AJ, Scambelluri M (2007) OH-bearing planar defects in olivine produced by the breakdown of ti-rich humite minerals from Dabie Shan (China). Contrib Mineral Petrol 153:417-428

Hirschmann MM, Aubaud C, Withers AC (2005) Storage capacity of $\mathrm{H}_{2} \mathrm{O}$ in nominally anhydrous minerals in the upper mantle. Earth Planet Sci Lett 236:167-181

Hirth G, Kohlstedt DL (1996) Water in the oceanic upper mantle: implications for rheology, melt extraction and the evolution of the lithosphere. Earth Planet Sci Lett 144:93-108

Karato S, Jung H (1998) Water, partial melting and the origin of the seismic low velocity zone in the upper mantle. Earth Planet Sci Lett 157:193-207

Kessel R, Ulmer P, Pettke T, Schmidt MW, Thompson AB (2004) A novel approach to determine high-pressure high-temperature fluid and melt compositions using diamond-trap experiments. Am Mineral 89:1078-1086

Kitamura M, Kondoh S, Morimoto N, Miller GH, Rossman GR, Putnis A (1987) Planar OH-bearing defects in mantle olivine. Nature 328:143-145

Kushiro I, Yoder HS (1969) Melting of forsterite and enstatite at high pressures under hydrous conditions. Carnegie Inst Wash Year B 67:153-158

Lee MR, Bland PA, Graham G (2003) Preparation of TEM samples by focused ion beam (FIB) techniques; applications to the study of clays and phyllosilicates in meteorites. Mineral Mag 67:581-592

Mysen BO (1979) Trace element partitioning between garnet peridotite minerals and water-rich vapor: experimental data from 5 to $30 \mathrm{kbar}$. Am Mineral 64:274-287

O'Neill HSC (1988) Systems $\mathrm{Fe}-\mathrm{O}$ and $\mathrm{Cu}-\mathrm{O}$ : thermodynamic data for the equilibria of $\mathrm{Fe}-$ " $\mathrm{FeO}$ ", $\mathrm{Fe}-\mathrm{Fe}_{3} \mathrm{O}_{4}$, " $\mathrm{FeO}$ " $-\mathrm{Fe}_{3} \mathrm{O}_{4}$, $\mathrm{Fe}_{3} \mathrm{O}_{4}-\mathrm{Fe}_{2} \mathrm{O}_{3}, \mathrm{Cu}-\mathrm{Cu}_{2} \mathrm{O}$ and $\mathrm{Cu}_{2} \mathrm{O}-\mathrm{CuO}$ from emf measurements. Am Mineral 73:470-487

O'Neill HSC, Pownceby MI (1993) Thermodynamic data from redox reactions at high temperatures. 1 . An experimental and theoretical assessment of the electrochemical method using stabilized zirconia electrolytes, with revised values for the $\mathrm{Fe}-\mathrm{FeO}, \mathrm{Co}-$ $\mathrm{CoO}, \mathrm{Ni}-\mathrm{NiO}$ and $\mathrm{Cu}-\mathrm{Cu}_{2} \mathrm{O}$ oxygen buffers, and new data from the $\mathrm{W}-\mathrm{WO}_{2}$ buffer. Contrib Mineral Petrol 114:296-314

Oehm J, Schneider A, Wedepohl KH (1983) Upper mantle rocks from basalts of the northern Hessian depression (NW Germany). Tschermaks Min Petr Mitt 32:25-48

Phaneuf MW (1999) Applications of focused ion beam microscopy to materials science specimens. Micron 30:277-288

Rauch M, Keppler H (2002) Water solubility in orthopyroxene. Contrib Mineral Petrol 143:525-536

Reed MH (1997) Hydrothermal alteration and its relationship to ore fluid composition. In: Barnes HL (ed) Geochemistry of hydrothermal ore deposits, 3rd edn. Wiley, New York, pp 303-366

Risold AC, Trommsdorff V, Grobéty B (2001) Genesis of ilmenite rods and palisades along humite-type defects in olivine from Alpe Arami. Contrib Mineral Petrol 140:619-628

Saal AE, Hauri EH, Langmuir CH, Perfit MR (2002) Vapour under saturation in primitive mid-ocean-ridge basalt and the volatile content of Earth's upper mantle. Nature 419:451-455 
Scambelluri M, Münthener O, Ottolini L, Pettke T, Vannucci R (2004) The fate of $\mathrm{B}, \mathrm{Cl}$ and $\mathrm{Li}$ in the subducted oceanic mantle and in the antigorite breakdown fluids. Earth Planet Sci Lett 222:217-234

Shmulovich KI, Graham CM (1996) Melting of albite and dehydration of brucite in $\mathrm{H}_{2} \mathrm{O}-\mathrm{NaCl}$ fluids to 9 kbars and $700-900{ }^{\circ} \mathrm{C}$ : implications for partial melting and water activities during high pressure metamorphism. Contrib Mineral Petrol 124:370-382

Stalder R, Ulmer P (2001) Phase relations of a serpentine composition between 5 and $14 \mathrm{GPa}$ : significance of clinohumite and phase $\mathrm{E}$ as water carriers into the transition zone. Contrib Mineral Petrol 140:670-679

Stalder R, Foley SF, Brey GP, Horn I (1998) Mineral-aqueous fluid partitioning of trace elements at $900-1,200{ }^{\circ} \mathrm{C}$ and $3.0-5.7 \mathrm{GPa}$ : new experimental data for garnet, clinopyroxene and rutile, and implications for mantle metasomatism. Geochim Cosmochim Acta 62:1781-1801

Stalder R, Ulmer P, Thompson AB, Günther D (2001) High pressure fluids in the system $\mathrm{MgO}-\mathrm{SiO}_{2}-\mathrm{H}_{2} \mathrm{O}$ under upper mantle conditions. Contrib Mineral Petrol 140:607-618

Stalder R, Klemme S, Ludwig T, Skogby H (2005) Hydrogen incorporation in orthopyroxene: interaction of different trivalent cations. Contrib Mineral Petrol 150:473-485

Stalder R, Kronz A, Simon K (2008) Hydrogen incorporation in enstatite in the system $\mathrm{MgO}-\mathrm{SiO}_{2}-\mathrm{H}_{2} \mathrm{O}-\mathrm{NaCl}$. Contrib Mineral Petrol 156:653-659

Tenner TJ, Hirschmann MM, Withers AC, Hervig RL (2009) Hydrogen partitioning between nominally anhydrous upper mantle minerals and melt between 3 and $5 \mathrm{GPa}$ and applications to hydrous peridotite partial melting. Chem Geol 262:42-56

Ulmer P, Trommsdorff V (1999) Phase relations of hydrous mantle subducting to $300 \mathrm{~km}$. In: Fei Y, Berthka CM, Mysen B (eds) Mantle petrology: field observations and high pressure experimentation: a tribute to Francis R. (Joe) Boyd. The Geochemical Society, Special publication No. 6, pp 259-281

Vigneresse JL (2009) Evaluation of the chemical reactivity of the fluid phase through hard-soft acid-base concepts in magmatic intrusions with applications to ore generation. Chem Geol 263:69-81

Webster JD, Sintoni MF, De Vivo B (2009) The partitioning behavior of $\mathrm{Cl}, \mathrm{S}$ and $\mathrm{H}_{2} \mathrm{O}$ in aqueous vapor- \pm saline liquid saturated phonolitic and trachytic melts at $200 \mathrm{MPa}$. Chem Geol 263: 19-63

Weiss M (1997) Clinohumites: a field and experimental study. Dissertation, ETH-Zürich

Wirth R (2004) Focused ion beam (FIB): a novel technology for advanced application of micro- and nanoanalysis in geosciences and applied mineralogy. Eur J Mineral 16:863-876

Wirth R, Dobrzhinetskaya L, Green HW II (2001) Electron microscope study of the reaction olivine $+\mathrm{H}_{2} \mathrm{O}+\mathrm{TiO}_{2}=$ titanian clinohumite + titanian chondrodite synthesized at $8 \mathrm{GPa}$, 1,300 K. Am Mineral 86:601-610

Yardley BWD (2005) Metal concentrations in crustal fluids and their relationship to ore formation. Econ Geol 100:613-632 